\title{
Beryllium toxicity
}

\author{
The selective inhibition of casein kinase 1
}

\author{
Bruce CUMMINGS, Matthew R. KASER, Gail WIGGINS, Margery G. ORD and \\ Lloyd A. STOCKEN \\ Department of Biochemistry, University of Oxford, South Parks Road, Oxford OX1 3QU, U.K.
}

(Received 7 June 1982/Accepted 19 July 1982)

\begin{abstract}
1. Cyclic AMP-independent casein kinase 1 in liver cytoplasm and nuclei was inhibited by $\mathrm{Be}^{2+}$ in vitro $\left(K_{\mathrm{i}} 2.5 \mu \mathrm{M}\right.$ and $29 \mu \mathrm{M}$ respectively). Casein kinase 2 (phosvitin kinase) and cyclic AMP-dependent protein kinase were unaffected. 2. The inhibition of casein kinase 1 by $\mathrm{Be}^{2+}$ was competitive with respect to the protein substrate; at non-saturating concentrations of casein, inhibition was non-competitive with respect to ATP. 3. In rats given $\mathrm{LD}_{50}$ doses of $\mathrm{Be}^{2+} 24 \mathrm{~h}$ before death, the activities of cytoplasmic and nuclear casein kinase 1 in livers from partially hepatectomized animals were diminished approx. $50 \%$; with intact rats, nuclear casein kinase 1 was inhibited at concentrations of casein less than the $K_{\mathrm{m}}$.
\end{abstract}

The basis of beryllium toxicity to mammals is not yet understood. $\mathrm{Be}^{2+}$, given to rats intravenously as $\mathrm{BeSO}_{4} /$ sulphosalicylic acid $(1: 1, \mathrm{~mol} / \mathrm{mol})$, is taken up into the liver lysosomes and then redistributed through the cells (Skilleter \& Price, 1980). Enzyme induction in normal and regenerating rat livers (Witschi \& Marchand, 1971; Witschi, 1970; Ord \& Stocken, 1981a) and soluble cytoplasmic protein kinases (Kaser et al., 1980) are inhibited, as is the phosphorylation of histone $\mathrm{H} 2 \mathrm{~A}$ in normal liver and of histone $\mathrm{H} 2 \mathrm{~A}$ and other histones at the transition from $G_{1}$ - to $S$-phase in regenerating livers (Kaser et al., 1980). Nuclear non-histone proteins extracted in $0.35 \mathrm{M}-\mathrm{NaCl}$ did not show diminished $\left[{ }^{32} \mathrm{P}\right] \mathrm{P}_{\mathrm{i}}$ uptake in rats given $40 \mu \mathrm{mol}$ of $\mathrm{Be}^{2+} / \mathrm{kg}$ in vivo, but $\left.{ }^{32} \mathrm{P}\right] \mathrm{P}_{\mathrm{i}}$ incorporation was decreased into proteins from liver Hn-RNP particles from partially hepatectomized rats or from those that had been given dexamethasone $3 \mathrm{~h}$ previously (Ord \& Stocken, 1981a).

In the method of assay (Chen \& Walsh, 1974) then used for the kinases, $80 \%$ of the activity was attributable to cyclic AMP-dependent kinase (EC 2.7.1.37), suggesting that this was the enzyme sensitive to $\mathrm{Be}^{2+}$. This has now been re-examined with partially purified enzyme preparations from ox heart and rat liver nuclei and cytoplasm and found to be incorrect, a cyclic AMP-independent kinase which uses casein rather than phosvitin or protamine

Abbreviations used: Hn-RNP, heterogeneous ribonucleoprotein; SDS, sodium dodecyl sulphate. as substrate (casein kinase 1; Huang et al., 1982) being the $\mathrm{Be}^{2+}$-sensitive enzyme. The $\mathrm{Be}^{2+}$-sensitivity of this enzyme in liver cytoplasm and nuclei may facilitate the identification of the kinase(s) involved in nuclear-protein phosphorylation in normal and growing cells.

\section{Materials and methods}

\section{Enzyme preparations from ox heart}

Trimmed frozen ox heart was minced, suspended in 6 vol. of $4 \mathrm{~mm}$-EDTA/0.1\% (w/v) 2-mercaptoethanol, $\mathrm{pH} 7.5$, and homogenized for $1 \mathrm{~min}$ in a Waring Blendor. After centrifuging for $45 \mathrm{~min}$ at $3000 \mathrm{~g}$ the supernatant was adjusted to $40 \%$ saturation with $\left(\mathrm{NH}_{4}\right)_{2} \mathrm{SO}_{4}, \mathrm{pH} 7.5$, and the precipitate used as a source of cyclic AMP-dependent protein kinase holoenzyme. The catalytic subunit obtained from the $40 \%$-satd.- $\left(\mathrm{NH}_{4}\right)_{2} \mathrm{SO}_{4}$ supernatant was purified by passage over DEAESephadex A-25 (Chen \& Walsh, 1974).

\section{Rat liver soluble cyclic AMP-independent casein} kinases 1 and 2

Casein kinases 1 and 2 were prepared from liver cytoplasm and nuclei (rats $300-400 \mathrm{~g}$ body wt.) as shown in Fig. 1.

\section{Protein kinase assay system}

Protein substrate, $40 \mu \mathrm{l}$ (concentrations as given in Tables and Figures); $1 \mathrm{M}$-Tris $/ \mathrm{HCl} / 15 \mathrm{mM}-2$ mercaptoethanol, $\mathrm{pH} 7.0,25 \mu \mathrm{l} ; 10 \mathrm{mM}$-magnesium 


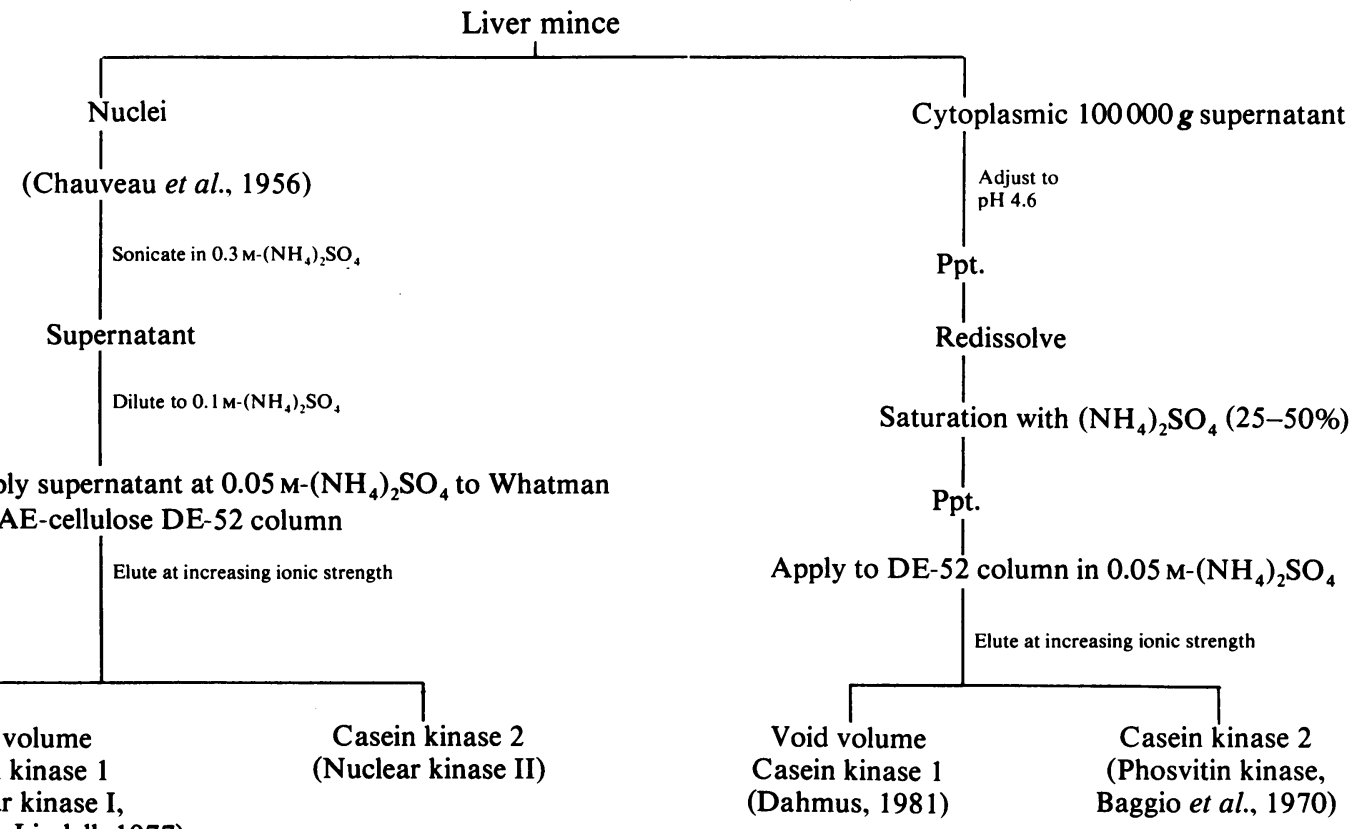

Thornburg \& Lindell, 1977)

Fig. 1. Separation of soluble rat liver cyclic AMP-independent protein kinases

acetate/10 mM- $\left.\gamma^{-32} \mathrm{P}\right] \mathrm{ATP}, \mathrm{pH} 7.0,20 \mu \mathrm{l}$; enzyme solution to $150 \mu \mathrm{l}$. The specific radioactivity of ATP was $0.3-1$ c.p.m./pmol. Tubes were kept at $0^{\circ}$ until the reaction was started by the addition of ATP; normally the incubation was for $15 \mathrm{~min}$ at $30^{\circ} \mathrm{C}$. At the end of the incubation, $50 \mu$ l of the mixture was transferred to a filtering apparatus (GF/C glass-fibre filters) and the filters washed in $10 \%(w / v)$ trichloroacetic acid and acetone before determining the ${ }^{32} \mathrm{P}$ transferred. In experiments when $\mathrm{Be}^{2+}$ was present, the $\mathrm{Be}^{2+}$ was used as a 1:1 molar mixture with sulphosalicylic acid; unless otherwise stated the $\mathrm{Be}^{2+}$ was added to the enzyme preparation before the substrates.

$\left[\gamma^{-32} P\right] A T P$

This was prepared by the method of Post \& Sen (1967).

\section{Chemicals}

Cyclic AMP-dependent protein kinase (crude and the catalytic subunit) and protein kinase inhibitor were obtained from Sigma (London) Chemical Co. (catalogue nos. P4890, P2645 and P8140). [ $\left.{ }^{32} \mathrm{P}\right] \mathrm{P}_{\mathrm{i}}$ was obtained from Amersham International. Histones were prepared from the rat liver nuclei by standard methods (Ord \& Stocken, 1975).

\section{Results and discussion}

Of the soluble protein kinases examined (Table 1), only the cyclic AMP-independent casein kinase 1 from liver nuclei and cytoplasm appeared to be sensitive to $\mathrm{Be}^{2+}$ inhibition in vitro. The inhibition by $\mathrm{Be}^{2+}$ was competitive with respect to the protein substrate (Figs. $2 a, 2 b$ and $2 c$ ) and at non-saturating substrate concentrations, non-competitive with respect to ATP (Fig. 2d). The inhibition studies were performed with enzymes, eluted from Whatman DEAE-cellulose DE-52 columns (thereafter termed simply 'DE-52 columns'), which were not homogeneous on SDS/polyacrylamide-gel electrophoresis. Casein kinase 1 from the cytosol had a $K_{\mathrm{m}}$ for casein of $6.25 \mathrm{mg} / \mathrm{ml}$ and $K_{1}\left(\mathrm{Be}^{2+}\right)$ of $2.5 \mu \mathrm{M}$; the nuclear enzyme had a $K_{\mathrm{m}}$ (casein) of $5 \mathrm{mg} / \mathrm{ml}$ and $K_{1}\left(\mathrm{Be}^{2+}\right)$ of $29 \mu \mathrm{M}$. $K_{\mathrm{i}}$ values of $1-5 \mu \mathrm{M}$ have been reported for alkaline phosphatase and phosphoglucomutase, which are among the most $\mathrm{Be}^{2+}$ sensitive enzymes known (Reiner, 1970).

The effects of changing the order of addition of components in the assay system gave results consistent with the inhibitor kinetics; normally $\mathrm{Be}^{2+}$ was incubated with the enzyme for $5 \mathrm{~min}$ before the addition of casein, and the reaction was then started with ATP. If the order of addition of $\mathrm{Be}^{2+}$ and casein was reversed, inhibition of $\mathrm{Be}^{2+}$ was markedly decreased. If casein was added last, the order of addition of ATP and $\mathrm{Be}^{2+}$ did not effect the extent of inhibition.

The natural substrate(s) of casein kinases in the liver are not known; our partially purified cytoplasmic casein kinase 1 phosphorylated histone $\mathrm{H} 1$ at about $10 \%$ of the rate for casein. With protein 
Table 1. Properties of soluble protein kinases from ox heart and rat liver

Final concentrations: casein, $6.25 \mathrm{mg} / \mathrm{ml}$; phosvitin, $13.3 \mathrm{mg} / \mathrm{ml}$; protamine, $3.3 \mathrm{mg} / \mathrm{ml}$. Abbreviation used: NA, not assayed. The results are the means from at least two enzyme preparations.

Enzyme source

Ox heart

Holoenzyme

Catalytic subunit

Rat liver

Cytoplasm

Casein kinase

Casein kinase 2

Nuclei

Casein kinase

Casein kinase 2
Sensitivity to:

Relative activity towards:

$\overbrace{\begin{array}{c}10 \mu \mathrm{M}-\mathrm{Cyclic} \\ \mathrm{AMP}\end{array}}^{\begin{array}{c}\text { Protein kinase } \\ \text { inhibitor }\end{array}}$

Casein Phosvitin Protamine

Inhibition by $0.1 \mathrm{mM}-\mathrm{Be}^{2+}(\%)$

(substrate)

$<10$ (protamine)

$<10$ (protamine)

$\begin{array}{lll}\text { NA } & 23 & <10 \text { (protamine) } \\ 13 & 27 & <10 \text { (protamine) }\end{array}$

0.45

3.6

NA

NA

0.32

1.17
0.03

0.35

100 (casein)

$<10$ (phosvitin)

98 (casein) 30 (phosvitin)
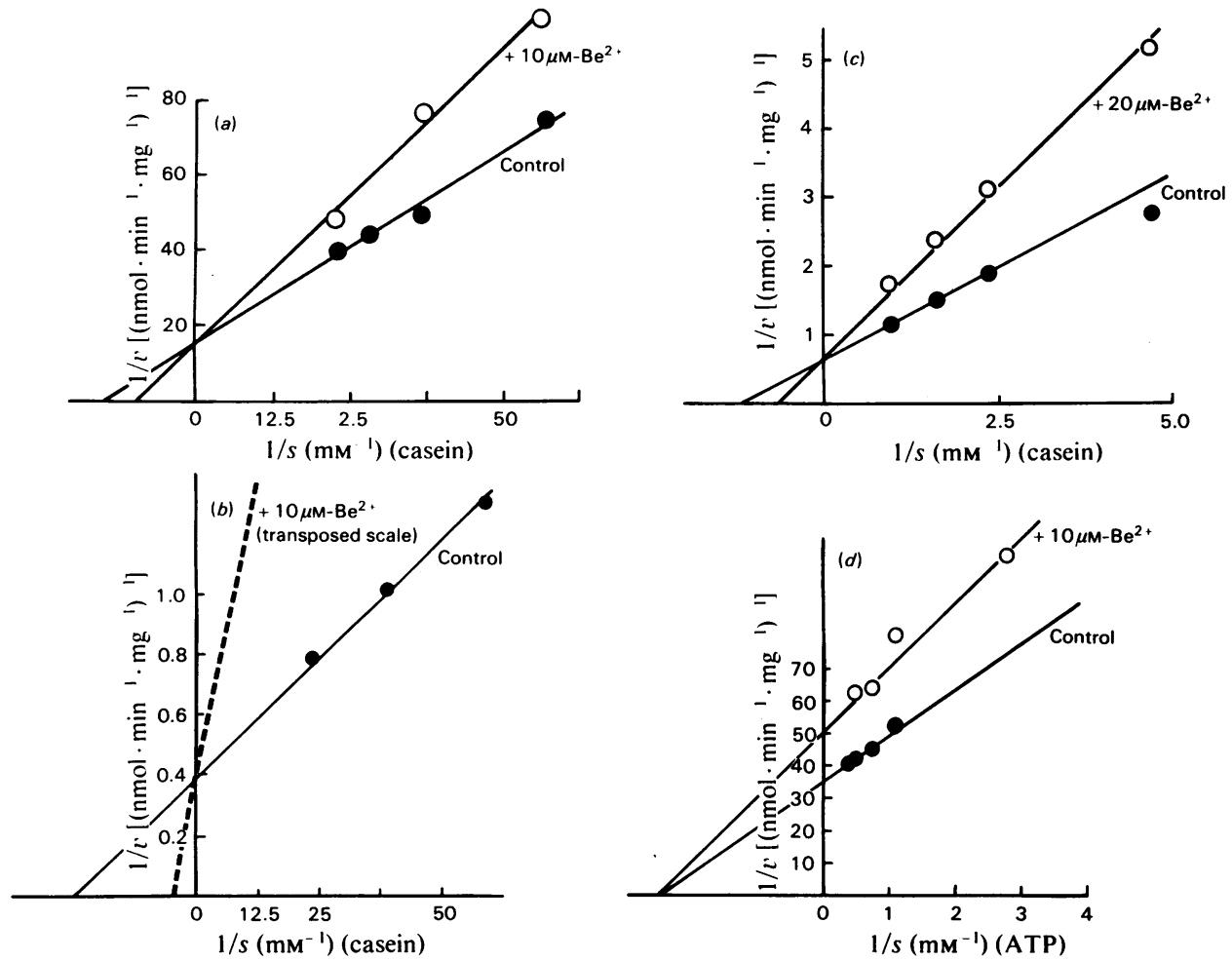

Fig. 2. Be $e^{2+}$ inhibition of casein kinase 1 from rat liver cytoplasm and nuclei

The enzymes were isolated and partially purified as outlined in Fig. 1. Where appropriate, $\mathrm{Be}^{2+}\left(\mathrm{BeSO}_{4} /\right.$ sulphosalicylic acid, 1:1) was incubated with enzyme for $5 \mathrm{~min}$ at $30^{\circ} \mathrm{C}$ before addition of the casein substrate. (a) Liver cytoplasmic enzyme was precipitated between 25 and $50 \%$ saturation with $\left(\mathrm{NH}_{4}\right)_{2} \mathrm{SO}_{4} ; 1.5 \mathrm{mg}$ of enzyme protein was used per assay. Concentrations of reactants were as follows: ATP, $2.6 \mathrm{mM} ; \mathrm{Be}^{2+}, 10 \mu \mathrm{M}$; casein, various. (b) Liver cytoplasmic enzyme was the void-volume fraction off the DE-52 columns; $85 \mu \mathrm{g}$ of enzyme protein was used per assay. Concentrations of $\mathrm{ATP}, \mathrm{Be}^{2+}$ and casein were as in $(a)$. The results in the presence of $\mathrm{Be}^{2+}$ have been transposed on the same scale as for the controls. (c) Liver nuclear enzyme was void-volume fraction off the DE-52 columns; $64 \mu \mathrm{g}$ of enzyme protein was used per assay. Concentrations of reactants were as follows: ATP, $2.6 \mathrm{mM}$; $\mathrm{Be}^{2+}, 20 \mu \mathrm{M}$; casein, various. (d) Liver cytoplasmic enzyme was void-volume fraction off the DE-52 columns; $85 \mu \mathrm{g}$ of enzyme protein was used per assay. Concentrations of reactants were as follows: casein, $6.25 \mathrm{mg} / \mathrm{ml} ; \mathrm{Be}^{2+}, 10 \mu \mathrm{M}$; ATP, various. $\bullet$, Control; $\mathrm{O},+\mathrm{Be}^{2+}$. 

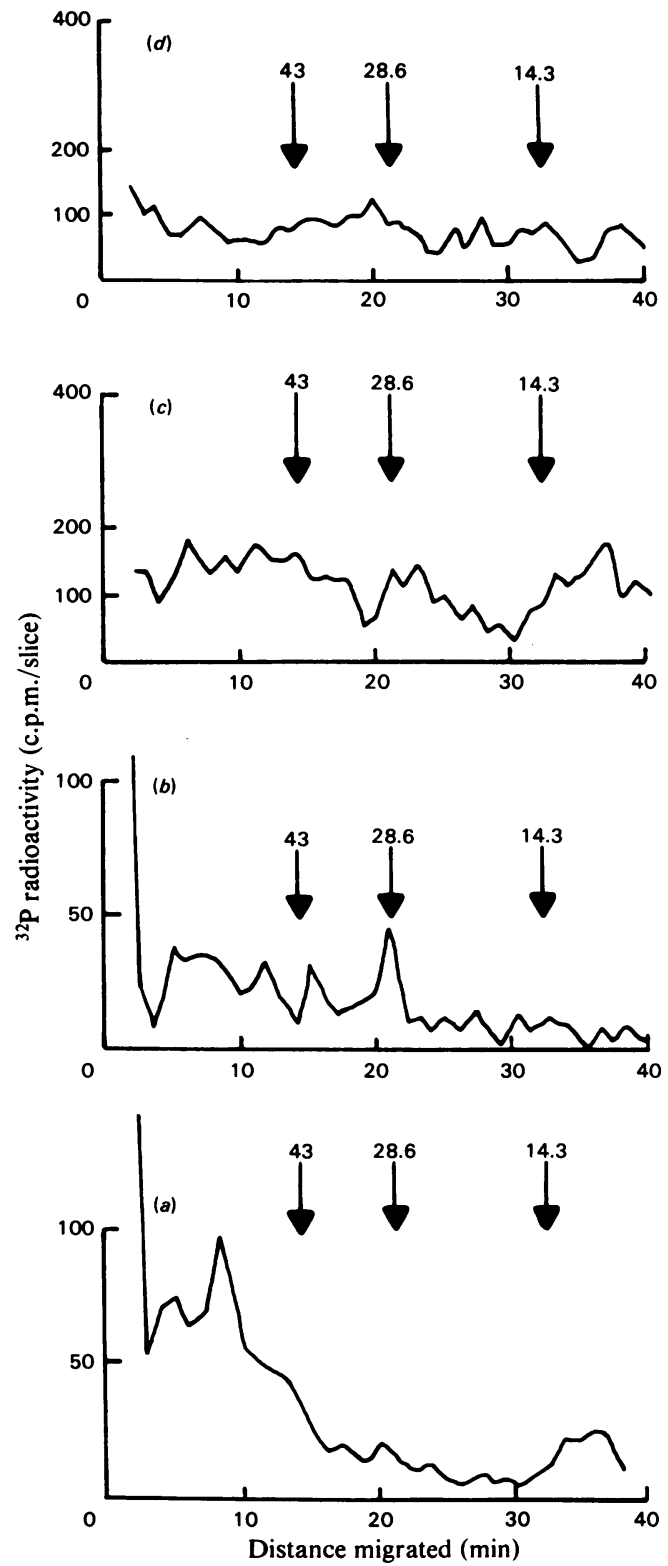

Fig. 3. SDS/polyacrylamide-gel electrophoresis of ${ }^{32} P$ incorporation by nuclear casein kinase into non-histone proteins and histones

Equal amounts of material were analysed (Weber \& Osborn, 1969) from control preparations $(a, c)$ and from those incubated with $50 \mu \mathrm{M}-\mathrm{Be}^{2+}(b, d)$. Slices $(2 \mathrm{~mm})$ were digested and their ${ }^{32} \mathrm{P}$ radioactivity determined. The position of molecular-mass markers (values in $\mathrm{kDa}$ ) is indicated by the arrows. ( $a$ and $b$ ) Crude nuclear enzyme $[25-50 \%$ saturation with $\left(\mathrm{NH}_{4}\right)_{2} \mathrm{SO}_{4}$; see Fig. 1]. No substrates were added. (c and $d$ ) Nuclear enzyme (void-volume fraction from the DE-52 columns) incubated with non-histone proteins extracted from rat liver nuclei in $0.35 \mathrm{M}$ $\mathrm{NaCl}$. substrates at $0.25 \mathrm{mM}, 10 \mu \mathrm{M}-\mathrm{Be}^{2+}$ inhibited the phosphorylation of casein by $33 \%$ and histone $\mathrm{H} 1$ by $44 \%$. The crude nuclear enzyme applied to the DE-52 columns still had associated with it phosphorylatable non-histone proteins and histones (Figs. $3 a$ and $3 b$; Table 2); ${ }^{32} \mathrm{P}$ uptake into the non-histone proteins was $58 \%$ inhibited by $50 \mu \mathrm{M}$ $\mathrm{Be}^{2+}$ and $94 \%$ inhibited into the histones. The enzyme that was eluted in the void volume from the DE-52 columns did not contain significant amounts of endogenous substrate; its capacities to phosphorylate non-histone proteins and histone $\mathrm{H} 1$ (extracted together from liver nuclei in $0.35 \mathrm{M}-\mathrm{NaCl}$ ) were inhibited about $45 \%$ by $50 \mu \mathrm{M}-\mathrm{Be}^{2+}$ (Figs. $3 \mathrm{c}$ and $3 d$ ).

Equilibrium dialysis had shown strong and specific $\mathrm{Be}^{2+}$ binding to organelles and proteins of the liver (Aldridge, 1966; Witschi \& Aldridge, 1968). It was also observed (Parker \& Stevens, 1979) that most of the beryllium was bound to a highly phosphorylated fraction of the non-histone proteins and there was no binding to the histones. Our equilibrium-dialysis studies of ${ }^{7} \mathrm{Be}^{2+}$ binding on cytoplasmic casein kinase 1 in void-volume fractions from the DE-52 columns gave Scatchard plots which indicated the presence of material with a high-affinity binding for $\mathrm{Be}^{2+}\left(K_{\mathrm{d}}\right.$ approx $\left.0.2 \mu \mathrm{M}\right)$. Control experiments showed that the casein also bound $\mathrm{Be}^{2+}$ at $50 \mu \mathrm{M}$; one $\mathrm{Be}^{2+}$ ion being bound per molecule of casein $(25 \mathrm{kDa})$. In spite of the expectation that SDS would probably dissociate $\mathrm{Be}^{2+}$ from protein, we have also examined its binding by the cytoplasmic casein kinase fraction by using SDS/polyacrylamide-gel electrophoresis. ${ }^{7} \mathrm{Be}^{2+}$ was detected (Fig. 4a) on four main proteins $(67.5,62$, 45 and $42 \mathrm{kDa}$ ) as well as on a number of minor ones. Void-volume material eluted from the DE-52 columns was enriched in $39 \mathrm{kDa} \mathrm{Be} \mathrm{Be}^{2+}$-binding protein, relative amounts of the other binding materials being greatly decreased (Fig. 4b). Molecular masses of $40-45 \mathrm{kDa}$ have been reported for the $\alpha$ - and $\alpha^{\prime}$-subunits of casein kinase 2, which was present in the material applied to the DE-52 columns (Fig. 4a); the molecular mass of casein kinase 1 is in the range $34-40 \mathrm{kDa}$ (Huang et al., $1982)$, consistent with the main ${ }^{7} \mathrm{Be}^{2+}$-binding component in the void-volume fraction (Fig. $4 b$ ).

Casein kinase 1 was next isolated from intact or partially hepatectomized rats $24 \mathrm{~h}$ after they had received $40 \mu \mathrm{mol}$ of $\mathrm{BeSO}_{4} /$ sulphosalicylic acid per $\mathrm{kg}$ body wt. intravenously. To diminish casein phosphorylation by $\mathrm{Be}^{2+}$-insensitive kinases, partial purification of casein kinase 1 was required. Isolation and purification steps were performed in parallel with control and $\mathrm{Be}^{2+}$-treated animals. There was no evidence that $\mathrm{Be}^{2+}$ treatment caused detectable differences in the amounts of protein recovered at different stages of purification. In our previous 
Table 2. Effects of $\mathrm{Be}^{2+}$ in vivo on liver casein kinase 1 activity

Five to six intact rats or twelve to fifteen animals partially hepatectomized $22-24 \mathrm{~h}$ before death were used per group. $\mathrm{Be}^{2+}\left[40 \mu \mathrm{mol} / \mathrm{kg}\right.$ body wt. intravenously as $\mathrm{BeSO}_{4} /$ sulphosalicylic acid $\left.(1: 1, \mathrm{~mol} / \mathrm{mol})\right]$ was given $24 \mathrm{~h}$ before death. The enzymes were prepared as shown in Fig. 1.

$\begin{array}{cccccc}\text { Enzyme } & \begin{array}{c}\text { [Casein] } \\ (\mathrm{mg} / \mathrm{ml})\end{array} & \overbrace{\text { Controls }}^{\text {Intact rats }} & +\mathrm{Be}^{2+} & \overbrace{\text { Controls }}^{\text {Enzyme activity }} \begin{array}{c}\text { Partially hepatectomized rats } \\ \text { of protein) }\end{array} \\ \text { Cytoplasmic } & 6.25 & 0.3 \pm 0.02 & 0.49 & 0.42 & 0.26 \\ \text { Nuclear } & 1.50 & 0.06 & 0.12,0.18 & - & -\mathrm{Be}^{2+} \\ & 6.25 & 0.56 \pm 0.04 & 0.68 \pm 0.02 & 3.9 & 2.1 \\ & 1.50 & 0.06,0.07 & 0.01 \pm 0.01 & 0.40 \pm 0.05 & 0.21 \pm 0.02\end{array}$

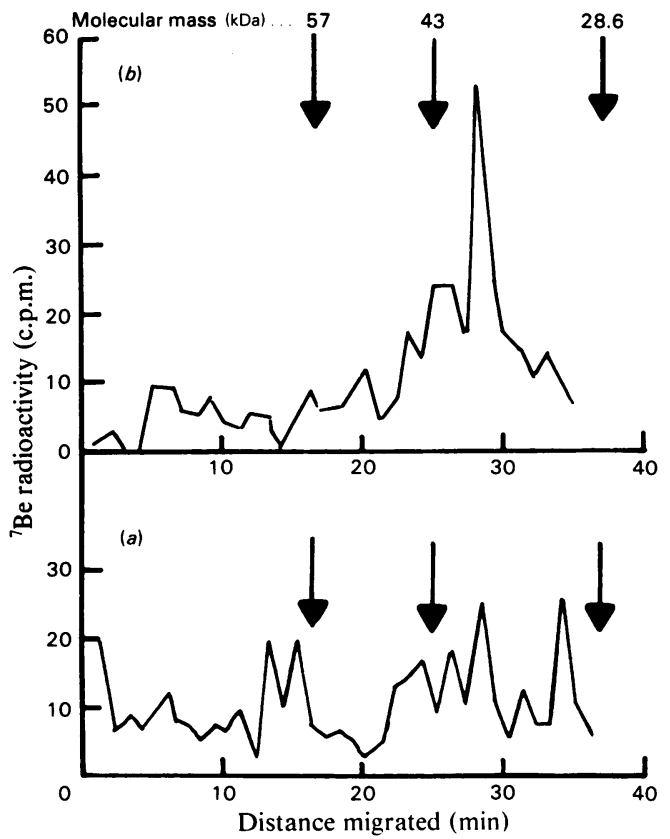

Fig. 4. SDS/polyacrylamide-gel electrophoresis of ${ }^{7} \mathrm{Be}^{2+}$ binding by cytoplasmic casein kinase 1

Crude enzyme $[30 \mu \mathrm{g} ; 25-50 \%$ saturation with $\left(\mathrm{NH}_{4}\right)_{2} \mathrm{SO}_{4} \mathrm{l}(a)$ or void-volume fraction off the DE-52 columns $(b)$ were incubated for $15 \mathrm{~min}$ at $30^{\circ} \mathrm{C}$ with ${ }^{7} \mathrm{Be}^{2+} \quad\left(5 \mathrm{mM}^{-7} \mathrm{BeSO}_{4} /\right.$ sulphosalicylic acid) before electrophoresis (Weber \& Osborn, 1969). After staining, the gels were sliced $(1 \mathrm{~mm})$ and the ${ }^{7} \mathrm{Be}$ radioactivity measured in a $\gamma$-radiation counter.

studies (Kaser et al., 1980), liver nuclei had been extracted with iso-osmolar solutions and the kinase activity measured. No diminution in activity had been detected in nuclei from normal or partially hepatectomized rats given $\mathrm{Be}^{2+} 17 \mathrm{~h}$ previously. Such iso-osmolar extracts contain predominantly cyclic AMP-dependent kinase and casein kinase 2, neither of which has now been found to be sensitive to $\mathrm{Be}^{2+}$ in vitro.

Casein kinase 1 activity in nuclei and cytoplasm was diminished by $40-50 \%$ from the $\mathrm{Be}^{2+}$-treated partially hepatectomized rats (Table 2 ). With intact rats, no inhibition of casein kinase 1 activity was found with cytoplasmic preparations, but was detected with nuclei from $\mathrm{Be}^{2+}$-treated animals if competition from the substrate was decreased by lowering the casein concentration from 6.25 to $1.5 \mathrm{mg} / \mathrm{ml}$ (Table 2). Beryllium diminishes inducible protein synthesis in liver. The effects of $\mathrm{Be}^{2+}$ on nuclear casein kinase 1 from normal livers were found only if substrate competition was decreased, so demonstrating the direct effect of $\mathrm{Be}^{2+}$ on the catalytic site of the kinase in vivo.

The proteins phosphorylated by liver casein kinase 1 in vivo are unknown, as is the essentiality of such phosphorylation. Casein kinase 1 preparations used here phosphorylated nuclear non-histone proteins and showed some activity towards histones. Histone phosphorylation, including that of histone $\mathrm{H} 2 \mathrm{~A}$ in resting liver nuclei, and the incorporation of ${ }^{32} \mathrm{P} \mid \mathrm{P}_{\mathrm{i}}$ into non-histone protein in $\mathrm{Hn}-\mathrm{RNP}$ particles, had previously been found to be inhibited in livers from $\mathrm{Be}^{2+}$-treated rats; the possibility now arises that the diminished phosphorylation is attributable to the selective inhibition of casein kinase 1 by $\mathrm{Be}^{2+}$.

Since constitutive protein synthesis in liver is unaffected by $\mathrm{Be}^{2+}$ (Witschi, 1970), the inhibitory effects of the metal ions resemble the actions of ionizing radiation, $\alpha$-blockers and procarcinogens (see Ord \& Stocken, 1981b) in selectively affecting induced rather than normal protein synthesis, and suggest that casein kinase 1 , which is firmly bound to the nuclear structure, may be involved in facilitating the induction process. 


\section{References}

Aldridge, W. N. (1966) Lab. Invest. 15, 176-180

Baggio, B., Pinna, L. A., Moret, V. \& Siliprandi, N. (1970) Biochim. Biophys. Acta 212, 515-517

Chauveau, J., Moulé, Y. \& Rouiller, Ch. (1956) Exp. Cell Res. 11, 317-321

Chen, L. J. \& Walsh, D. A. (1974) Methods Enzymol. 38, 323-329

Dahmus, M. E. (1981) J. Biol. Chem. 256, 3319-3325

Huang, K. P., Itarte, E., Singh, T. J. \& Akatsuka, A. (1982) J. Biol. Chem. 257, 3236-3242

Kaser, M. R., Ord, M. G. \& Stocken, L. A. (1980) Biochem. Int. 1, 148-154

Ord, M. G. \& Stocken, L. A. (1975) Proc. FEBS Meet. 9th 34, 113-125

Ord, M. G. \& Stocken, L. A. (1981a) Biosci. Rep. 1, 217-222

Ord, M. G. \& Stocken, L. A. (1981b) Biochem. Soc. Trans. 8, 759-766
Parker, V. H. \& Stevens, C. (1979) Chem.-Biol. Interact. 26, $167-177$

Post, R. L. \& Sen, A. K. (1967) Methods Enzymol. 10, 773-775

Reiner, E. (1970) A Symposium on Mechanisms of Toxicity (Aldridge, W. N., ed.), pp. 111-125, Macmillan, London

Skilleter, D. N. \& Price, R. J. (1980) Arch. Toxicol. 45, 75-80

Thornburg, W. \& Lindell, T. J. (1977) J. Biol. Chem. 252 , 6660-6665

Weber, K. \& Osborn, M. (1969) J. Biol. Chem. 244, 4406-4412

Witschi, H. P. (1970) Biochem. J. 120, 623-634

Witschi, H. P. \& Aldridge, W. N. (1968) Biochem. J. 106, 811-826

Witschi, H. P. \& Marchand, P. (1971) Toxicol. Appl. Pharmacol. 20, 565-572 